\title{
A Critical Analysis of Dramaturgy and Theatricality in Okwe Agbaala
}

\author{
*Nkoli Mercy Nnyigide \\ http://dx.doi.org/10.4314/ujah.v15i1.9
}

\section{Abstract}

It has been observed that some contemporary Igbo playwrights usually deviate from the standard form and structure of playwriting. Besides, some write without having the stage and theatre audience in mind. Consequently, they present some undramatic actions in their works. Unfortunately, this situation has left the written Igbo drama as ordinary literary text like the novel or poem which cannot be performed on the stage. As a result, some directors and actors no longer have interest in it. They now prefer those written in the English language. This situation is what engineered the study into examining the extent to which Nwadike has fared in achieving the art of theatre in his work. To get about this, the study adopts the literary theory of formalism in analyzing the text. Besides, some related literatures were reviewed. The findings revealed that: $i$. Okwe Agbaala is a good example of contemporary Igbo drama that can be performed on a modern theatre. ii. the work really conformed to the standard form and structure of playwriting. iii. some elements in the work can be improvised. $i v$. the study shows that there is a clear difference between the dramaturgy and theatricality of the contemporary Igbo drama and that of the Igbo traditional drama. However, the study recommends that young Igbo playwrights should be 
educated properly and encouraged to recognise the standard form of playwriting, as well as the importance of premier production before publishing their works. This would not only enhance their works but it would give them the privilege to observe how they have fared in communicating to their readers and audience.

\section{Introduction}

The Igbo drama is one of the major genres of Igbo literature. The structure and dramaturgy of a dramatic work determine the extent to which it can be realised on the theatre. Dramaturgy is the art of theatre. According to Encarta (2007), dramaturgy means the art of theatre, especially with regard to the techniques involved in writing plays. But theatricality deals with the characteristic of the theatre or dramatic performance. Besides, Wehmier, (2006:1532) defines theatricality as, "The exaggerated quality of something that is intended to attract attention or create a particular effect. The above definition shows that in a dramatic performance, some actions may be exaggerated in order to arouse emotional feelings of the audience. Furthermore, in defining dramaturgy, Mbah and Mbah (2007:323), says Dramaturgy is the art of dramatic composition. It concerns questions regarding the art of dramatic composition and the influences, if any, which have treaded the composition. Influences in composition are necessary because they play an important role in the understanding of a work of fiction especially drama.

In addition, "theatricality deals with the suitability of the end product of dramaturgy to the stage and in some other 
theatrical situations" (332). From the above definitions, it can be seen that a mastery of the art of dramaturgy and theatricality projects a good dramatic work. However, in the study of contemporary literary drama in the Igbo language, some scholars have observed that some playwrights, usually deviate from the standard form and structure of playwriting. Nwaozuzu (2007:73) says, Having directed quite number of plays in the Igbo language, the problems and challenges, which they present in performance, are quite familiar. These problems border mainly on structure, form and dramaturgy. Sadly, very few of these plays exhibit fluid and performative structures that yield easily to the stage. As a result, most directors would prefer to leave them to the closet which it would appear most of them were written for, and go for plays in the English language.

Going by the above definitions and observation, the study aims at examining the dramaturgy and theatricality in Okwe Agbaala. This is hoped to show the extent to which some dramatic elements are utilised in the work.

\section{Synopsis of Okwe Agbaala}

Okwe Agbaala is a contemporary Igbo drama. It was written by Uzoma Nwadike and published in 1991 by Macmillan Publishers. The story in the novel revolves around three major characters: Dr. Emezina- a Lecturer, Chinyere- a student and Ozuruigbo ( a.k.a. Fucho Prof)a student. In the story, while Ozuruigbo is presented as a hardworking and very intelligent student; Chinyere is 
presented as a flirt, dull and lazy student who wanted to pass her examination by all means, and Dr. Emezina as an irresponsible man who can have an extra-marital affair with his student; Chinyere. The theme of the novel centres on examination malpractice and its consequences. The incidence happens during the degree examination of Ozuruigbo and Chinyere. Before the examination, Dr. Emezina used to see Chinyere and Ozuruigbo together. He feels that they are having an affair. As a result he vows to deal with Ozuruigbo. Few days to the examination, Chinyere lures Dr. Emezina into having a sexual relationship with her and consequently, he releases his examination questions to her. On the day of the examination, Dr. Emezina takes Ozuruigbo's registration number and eventually seizes his result. When Ozuruigbo observes that his result is not published, he reports to the school authority. In reaction, the authority investigates the case and invites Dr. Emezina, Chinyere and Ozuruigbo to a panel. At the end when the truth is revealed, Dr. Emezina and Chinyere are punished. The former is expelled, the later is imprisoned and his appointment terminated. But Ozuruigbo is vindicated and rewarded.

\section{Theoretical Framework}

The study adopts the literary theory of formalism. . It is observed that some scholars use formalism and new criticism interchangeably. According to, Dobie (2009: 33), "Formalism probably has the distinction of having more names than any either recently developed school of criticism. The model, as defined by American and English critics, has been called New criticism..." 
Historically, according to Dobie (2009: 36),

The new criticism was more directly born as a reaction against the attention that scholars and teachers in the early part of the twentieth century paid to the biographical and historical context of a work, thereby diminishing the attention given to the literature itself. Instead of dealing with a poem, for example, they were likely to treat it as sociological or historical record. It could be an excuse to indulge one's fascination with the lives of writers and their friends.

Many scholars have made reasonable effort in defining and explaining the concept of formalism. According to Abrams (2005: 107),

Formalism views literature primarily as a specialized use of language and proposes a fundamental opposition between the literary (or poetical) use of language and the ordinary, "practical" use of language ... The linguistics of literature differs from the linguistics of practical discourse, because its laws are oriented toward producing the distinctive features that formalists call literariness.

Similarly, Dobie (2009: 35) observes that the language of literature is different from ordinary language because it deviates from the expected, using all the devices an author has the power to manipulate to make what is familiar seem strange and unfamiliar. From the above 
views, it could be seen that the linguistics of literature projects and contributes to the literariness of a literary work. Jakobson (as cited in Abrams, (2005) observes that "the object of study in literary science is not literature but "literariness", that is, what makes a given work a literary work.

Likewise, Rice and Waugh (2001: 43) are of the same view that formalism centres not so much on literature but literariness, that which makes a given text literary. They also observe that formalism focuses on the functioning of literary devices rather than on content. In support of the above views, Literary theory (2012: 2) says, "Formalism" is, as the name implies, an interpretive approach that emphasizes literary form and the study of literary devices within the text... Formalists placed great importance on the literariness of texts, those qualities that distinguished the literary from other kinds of writing".

According to Wishart (2010: 2), "The formalist perspective concentrates on the form of the literature itself". She also adds that "formalism allows the reader to analyse a literary piece with complete objectivity". Kennedy (as cited in Wishart (2010) says, "Formalists pay special attention to the formal features of the text the style, structure, imagery, tone and genre". In support of Wishart, Dobie (2012: 33) says,

Formalism's sustained popularity among readers comes primarily from the fact that it provides them with a way to understand and enjoy a work for its own inherent value as a 
piece of literary art. Emphasizing close reading of the work itself, formalism puts the focus on the text as literature.

From the above views, it can be seen that unlike other literary theories formalism concentrates on the literariness of a literary work.

\section{Dramaturgy and Theatricality in Okwe Agbaala: Plot}

This is the story line, that is, the sequence of action or events in a literary text- novel, play or poem. Gillespie, Fonseca and Sanger (1996:984), define plot as, "the arrangement of the events in a story according to a pattern devised by the writer and inferred by the reader". They further add that, "Plot develops when characters and situations oppose each other, creating conflicts that grow and eventually reach a climax, the point of highest intensity of the story. After this climatic turning point, the action of the story finally declines, moving toward a resolution of the conflict". A tragic literary work is usually presented in the above order.

Also, Brockett (1974:35), says that, "Plot includes the story line, it refers as well to the organization of all the elements into a meaningful pattern.., plot is the over-all structure of a play". He goes further to explain that, "In some dramas both the story and its arrangement may seem vague, but nevertheless, all plays have plots, however tenuous they may be". Again, Hornby, (1986:887), defines plot as, "The series of events which form the story of a novel, play, film/movie, etc". 
In addition, a novel, play or poem may have a sequential plot. That is, the story may start from the beginning, through the middle to the end, while some start from the end to the beginning. The arrangement of a plot of a literary text sequentially makes it more coherent. Secondly, observation has shown that in the arrangement of a literary work, the use of flashback, suspense and digression by writers do make their works very interesting.

In Okwe Agbaala, the story starts from the university, with Chinyere during an examination period. From there the action starts to mount as the lecturer gives Chinyere the secret question paper and also copies Ozuruigbo's registration number during the examination. The climax of the play is when he finds out that his result is not published. The story in the play ends when the lecturer and Chinyere are punished and Ozuruigbo rewarded. The play is divided into three major phases. The action in each phase leads to the other. In other words it has an episodic plot and this helped to enhance the literariness of the work.

\section{Theme}

Beaty et al. (1992:223) defines theme as "The central idea, the thesis, or even the message of the story". Usually, in a prose, drama or poem, a critic may discover the major theme and other sub-themes. The major theme is the central or main idea the writer wishes to share with his audience, while the sub-themes are the moral lessons the write wants his audience to understand.

In Okwe Agbaala, the major theme centres on the high rate of examination malpractices in some institutions of 
higher learning and their adverse effects on the culprits. This is seen in the characters of Dkt Emezina and Chinyere Egbule. Chinyere is presented as a lazy student who desired to pass her examinations by all means. To achieve this she lures Dkt Emezina; her lecturer, into having a sexual relationship with her. She believes in using what she has to get what she does not have. This manifested in her song on page three;

Ama m si ukwu bụ ego Do I know that waist is Mụ ewere nke $m$ agba money bongo I play with my own

Ama m sị ukwu bụ ego Do I know that waist is ooo.... . money...

She seemingly succeeded but fate turns against her as the truth is unveiled and consequently, she is expelled. On the other hand, her accomplice, Dkt Emezina (the lecturer) is imprisoned and his appointment is also terminated.

Apart from the major theme, other vices the writer exposes in the work include:

i. Victimization: This is revealed through the characters of Dkt. Emezina and his student; Ozuruigbo. Dkt. Emezina suspects that Ozuruigbo is having an affair with his girl friend, Chinyere. As a result of this, he takes Ozuruiigbo's registration number on the day of his degree examination and eventually seized his result. This is seen in Ozuruigbo's statement on page 41 thus;

... Ala arụọlanụ !

...abomination 
ụnụ makwa na onye nkuzi Do u know that the lecturer kọpịịla nọmba $\mathrm{m}$ Took my registration number.

ii. Pretence and betrayal. This is seen in the characters of Dkt Emezina and Chinyere. At the initial stage, Chinyere pretends to be friendly with Dkt. Emezina; as seen on pages $22 \& 26$;

Dọk, biko

Bikozinụ

Wedakwanụ obi

Obi gị abụdị nkume?

... egwu atụla gị .

Onye m kwọ n'azụ

Ụkwụ anaghị akpụ ya n' ala.
Dr, please

Please

Calm down

Is your heart a stone?

...do not be afraid

Whoever that I am backing His leg does not touch the ground

Notwithstanding the assurance she gives to Dr. Emezina, she later betrays him, as seen in her false allegation in the law court, as thus;

E nweghị onye $m$ jekwuuru

kama o bụ Dkt Emezina kpọrọ $\mathrm{m}$

N'ofiisi ya nye m ajụjụ ule iji rata $m$ ka mụ na ya mekọọ . (pg 65).

I did not go to anybody

But it was Dr. Emezina that called me

In his office and gave me the examination question In order to lure me.

iii. Unfaithfulness and irresponsibility. This is seen in the characters of Dr. Emezina and Chinyere. Dkt 
Emezina is presented as a married man and it is expected that a married man ought not to have an extra-marital affair. However, Dr. Emezina out of his weakness, irresponsibility and unfaithfulness berates himself and allows Chinyere; his student to kiss him and also to sit on his laps. In reaction, he admires Chinyere and says, on page 25 ;

... mgbe ahụ ị na-edesịsị anya mmiri Ka m chọputara na ị $\begin{array}{ll}\text { really beautiful } \\ \text { When you were crying. }\end{array}$ bụkwanụ asa.

I realized that you are

Again, Dr. Emezina's act of unfaithfulness and irresponsibility also manifests when he gives Chinyere the secret questions that are set for the examination as can be seen on page 26 ,

Nwaada,

Lee ya,

Tọo skriit!

Biko...
Miss,

See it

Top secret

Please...

Ekwekwala anya ọzọ hụ Do not let any other person ya. see it.

Furthermore, it is seen in the play that anything that is hidden must be revealed and that every deed; whether good or bad must surely be rewarded accordingly. In the work, fair judgement prevails. Chinyere and Dkt Emezina are really punished for their evil deeds while Ozuruigbo is vindicated and rewarded thus; 
A na $\mathrm{m}$ atụ gi mkpọrọ I sentence you to two years gbalụ gbalụ afọ abụọ. imprisonment.

N'etikwa iwu ka a chụọ I also decree that you be gị n'ọu Mahadum. sacked from the university

N'ebe ukwu na-eri ego bụ In the case of the flirt; Chinyere nọ, Chinyere

Ana $\mathrm{m}$ etikwa iwu ka a I order the cancellation of kagbuo ule digrii ya your degree result

Ma chụọwa ya na And your expulsion from Mahadum kpamkpam, the university.

N'ebe nwa okoro bụ In the case of the young Ozuruigbo nọ , man Ozuruigbo

Ana $\mathrm{m}$ akpọku ndi na- I call on the university achị Mahadum management

Ka ha lebaghari a anya To look into your answer n’ule akwụkwọ ya, script

Bia nye ya ọwa ruuru ya And give you the real result n'ule digrii ahụ . (pg 7 1-72). of your degree examination.

The above themes helped to project the literariness of the work.

\section{Setting}

In defining setting, Abrams (2005:294) says, "The overall setting of a narrative or dramatic work is the general locale, historical time, and social circumstances in which its action occurs; the setting of a single episode or scene within the work is the particular physical location in which it takes place". From Abrams definition, one can see that setting has to do with the particular time and place where the action in the story 
took place. Nwadike (1992:78-80) explains that the setting of a literary work can be the place, time- past, present or future and the circumstance in which the actions in the work takes place. In support of Nwadike, Gillespie, Fonseca and Sanger (1996:985) remark "The time, place and social context of a story constitute its setting". For example, the time may be pre-colonial or post-colonial era, as can be seen in Omenuko. As a reader reads through a literary work, he or she should watch out for details related to time, place and social context that reveal the motivation of the protagonist and establish the story's credibility. Also, he or she ought to pay attention to the writer's use of visual imagery aimed at helping him to create mental pictures of the setting and assess its effects on the characters' actions. Also, if a reader reads and observes that the writer mentions schools, churches, hospitals, court, office, et cetera, as could be seen in the work under review, he or she can conclude that the work is a modern work. In the case of place, a writer can create or imagine his own place(s) as can be seen in Nwata Rie Awo . Places like Amaudele, Isungodo, are fictitious. In drama, acts and scenes, places like- market, village square, school, bush, can be the setting of a particular work.

Okwe Agbaala is a contemporary Igbo drama. It is set in the $21^{\text {st }}$ century university environment. The work reveals some of the vices and ills that take place in some universities nowadays. Other places the actions in the work takes place include: university of Alaubi, Chinyere's room, class room, Dr. Emezina's office, 
Dean's office, law court, hotel de jeneral isi ewu, et cetera.

\section{Character and Characterization}

A character may be a person or an animal in a book, play, or film or movie. In the work under review, the characters are all human beings (persons). It is observed that there are major and minor characters in the work. The major characters are the ones around whom the actions of the play revolve. That is, they play the major roles. A major character can be a flat character or a round character which means; he can remain static in his ideal even as the situation in the play changes or he can change his ideal even as the situation in the play changes. Furthermore, minor characters are the ones who compliment both the action of the play and that of the major characters.

Brockett, (1974: 33) says that a character is identified by what he says, what he does, what other characters in the story say about him and what the writer says about him. Characterization on the other hand is the description of characters in a literary work through the characters' attitudes and behaviours. Brockett, (p.34) also defines characterization as the writer's means of describing the dramatic personage in his work. Brockett goes further to explain that characterization is revealed in the following levels:

a. Physical level: this has to do with the physical qualities of a character, as in the size, height, colour, etc. b. Social level: this has to do with the economic status, profession, etc of a character. 
c. Psychological level: this has to do with the character's belief, likes, dislikes, etc.

d. Moral level: this has to do with the character's choice in facing moral crises.

In Okwe Agbaala, the major characters are Chinyere, Dokita Emezina and Ozuruigbo. Chinyere and Ozuruigbo are flat characters because they did not change their ideal even as the situation in the play changes. But Dokita Emezina is a round character because he changes his ideal as the situation in the play changes

Besides, Ozuruigbo is presented as an industrious, diligent and intelligent student, who believes in hard work and its reward. On the contrary, Chinyere was presented as a flirt, lazy and dull student, who believes that she can use her body to get whatever she wants. In the case of Dr. Emezina, he is presented as a very weak, unfaithful and irresponsible man. All the characters in the play worked together to enhance the literariness of the work

\section{Language}

This is the medium through which a writer communicates to his reader, audience or critic. The writer expresses his ideas, opinions, feelings, experiences, etc through language. Artistic use of language by creative writers brings out the power of language which makes the reader to fear, cry, smile, love etc. as they read. In creative writing, language is used to bring out the aesthetic quality of a creative work. 
According to Hornby (1989:662), he defines language as, "The system of sounds and words used by humans to express their thoughts and feelings". In literature, language is very important. Language is literature. It is the major element of prose, drama and poetry. Authors use language to communicate their ideas, feelings, message, and opinions to the audience. Some figurative languages like hyperbole, metaphor, simile, irony, euphemism, etc are used by authors to bring out the beauty, the aesthetic nature and the real effect of their works. Though theme, plot, setting, character and characterization, are elements of literary works; to convey these to an audience, the writer has at his disposal only two means, sound and spectacle. Sound includes language, music and other aural effects. In literary studies, language is regarded as the most essential tool a writer uses to convey his message to the readers or audience. In order words, it is the writer's primary means of expression.

It is observed that Okwe Agbaala is written in Igbo language, but due to the nature of the work, the playwright mainly used "Igbonization" which is the spelling of English words in Igbo. Examples of some "igbonized" words are:"yuu havu to filosofaize", lekcho (pg 6), distinkshon, kredit, meriti (pg 8), lekchora, 'koodu ofu kondoktu', reputeshon (pg 23) etc. These words are used to project the actual setting of the work. $\mathrm{He}$ also beautifies his work with some slangs, figurative expressions and rhetorical questions example:

S1ang- bongo, koso, apiriko (pg 3), akada (pg 4) et cetera. 


\section{Figurative expressions}

We1lerism- e.g Nkịta sị mgbe ọ bụla ya na-eri nsị , onye akpọkwarala ya ihe ojo aha (pg 5), etc:

(Dog says that whenever it is eating faeces, nobody should remind it of nauseating things)

Proverbs- e.g. anyị akpụchaala ara tupu di abịawala anyị (pg 6): (We've sprouted breasts before suitors started coming), ụra tọwa ụto , e kwowe ya ekwowe (pg 9),( Snoring starts when sleep becomes enjoyable), ọchụ nwa ọkụkọ nwe ada, nwa ọkụkọ nwe nwenwe (sic) ọsọ (pg 11): (It is for the chicken to have wobbly run while the chasers falls as $s / h e /$ it chases it about): nwaturu gaepu mpi ekwo kakwaa ya akaa (pg 32) ( The lamb that feels it is old enough to sprout horn should be ready for the whatever that goes with it)etc.

Hyperbole- e.g. anya $m$ hụrụ ntị $m$ taa n' ejighị enyo (pg 31), etc: ( My eyes saw my ears today without mirror).

Paradox- e.g. ndị nkịta ga-agbọ ụja na Hotel de jeneral isi ewu ugbu a bu anyi (pg 30), etc: (It is our turn to be barked at by the dog at Hotel de jeneral isi ewu).

Personification-e.g. mgbe ufọdụ, ule na-atụ mmadụ aka nwa "enwe" (pg 43): ( Sometimes examinations tend to be very unfavourable), a hapụ Dkt. Emezina ka ọ laa, eziokwu agaa njem alọtaghị alọta (pg 68) etc.( If you let Dkt. Emezina free, then the truth will embark on a journey of no return).

Rhetorical questions- e.g. a ga-agbanye mmadụ aja n'anya sị ya akụchasịla ya? (pg 45), (Would one pour sand on another's eyes and insist that s/he shouldn't clean his/her eyes?), a ga-eti nwata ihe sịkwa ya ebele 
akwa? (pg 46) etc. (Would one beat a child and prevent him/her from crying?)

The above figurative expressions are used to enhance the literariness and aesthetics of the work.

\section{Props and Set}

According to Obah (2009), props are objects used by actors during a performance of a play or in a film/movie, while set has to do with the architectural configuration or design on a stage which complements the drama or play. In Okwe Agbaala, the following props are employed: text books, exercise books, school bags, chairs, tables, radio, chalk, chalk board, book shelf, etc. While the set used were law court, class room, offices, hotel, etc.

\section{Costume and Make up}

According to Encarta (2009), costume means theatrical clothes worn to make a person look like somebody else, especially in a theatrical performance. While make-up means to prepare somebody for an acting performance by applying cosmetics and fitting costumes necessary for assuming a given role. In Okwe Agbaala, contemporary costume and make up such as: jeans trousers, skimpy dresses (for females), modern cosmetics, etc are used.

\section{Mood}

In Okwe Agbaala, the general mood depicted is unsympathetic. Nobody, felt sorry or pity for Dọkita Emezina and Chinyere when unpleasant situation came upon them. That is when they are sacked and expelled respectively. 


\section{Light}

There is representation of light in the work. After the prologue the light fades and the actions start immediately. Likewise, after the epilogue, the light finally fades, showing that the actions have come to an end.

\section{Summary and Conclusion}

The study has been able to examine the dramaturgy and theatricality in Okwe Agbaala. It observes that some actions in some modern Igbo drama can be achieved on the stage. Therefore, the study reveals that Okwe Agbaala is a good example of contemporary Igbo drama that can be performed on modern theatre. Besides, the dramaturgy and theatricality in the work really help to promote its literariness. However, the study recommends that seminars, workshops, etc should be organized for young Igbo playwrights in order to educate them on the basic standard of playwriting. This will not only enhance their works but it will help to promote the interest people have for the Igbo plays.

Nkoli Mercy Nnyigide is of the Department of Asian \& African Studies, Nnamdi Azikiwe University, Awka, Nigeria. 


\section{References}

Abrams, M. (2005). A Glossary of Literary Terms, USA: Thomson Higher Education.

A. S. Hornby, (1986), Oxford Advanced Learners Dictionary Of Current English, New York: Oxford University Press.

Beaty et al, (2002), The Norton Introduction to Literature, New York: Norton \& Company.

Dobie, A. B. (2012) Theory into Practice: An Introduction to Literary Criticism. USA: Wadsworth.

Dobie, A. B. (2009) Theory into Practice: An Introduction to Literary Criticism. Boston: Wadsworth.

Literary Theories. (2012). "Literary Theories: A Sample of Critical Lenses". Retrieved from http://www.google.com/search

Mbah, B. M. and Mbah, E. E. (2007), Azuonye: Lectures on Igbo Literature and Stylistisc, Nsukka: University of Nigeria Press.

Microsoft Encarta, (2009), Microsoft Corporation.

Nwadike, I. U. (1991), Okwe Abgaala, Owerri: Macmillan.

Nwadike, I. U, (1992), Ntọla Agụmagụ,Nigeria: Ifụnanya.

Nwana, P. (1963) Omenuko. Enugu: Longman. 
Nwaozuzu, U. C. (2007), "Text, Performance and Theatricality: A Stage Director's Evaluation of Contemporary Igbo Literary Drama" in Anasiudu, B.N., Nwaozuzu, C.N., Okebalama, C.N. (Eds.).Language and Literature in a Developing Country, Essays in honour of Professor Benson, O.A. Oluikpe, Onitsha pp. 7379.

Obah, J. O., (2009), Mimeograph.

Onyekaonwu, G.O. (1989). Nwata Rie Awo, Onitsha:University Press.

Oscar Brockett, (1974), The Theatre, an Introduction, New York: Holt, Rinehart and Winston.

Rice, P. and Waugh, P. (2001). Modern Literary Theory. Britain: Oxford University Press.

Sheena Gillespie, Terezinha Fonseca and Carol Sanger, (1996), Literature Across Culture, New York: Allyn and Bacom.

Wehmeier Sally (Ed.), (2005), Oxford Advanced Learner's Dictionary, New York: Oxford University Press.

Wishart, C. (2010). "Analyzing Literature: The Formalistic Perspective". Retrieved from http://www.google.com/search 